\title{
Outward foreign direct investment and corporate green innovation: An institutional pressure perspective
}

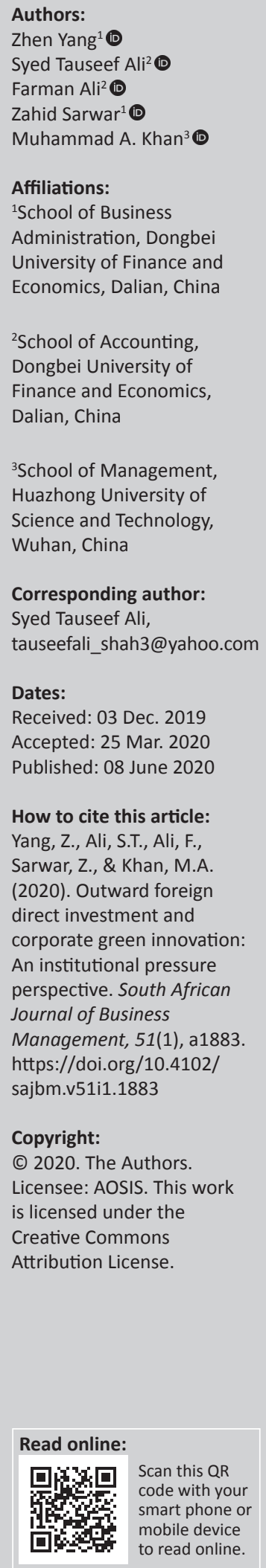

Purpose: Institutional theory is a reasonable explanation for the motives of corporate social responsibility (CSR) behaviours (e.g. corporate green innovation). The existing literature defines institutional pressure as threats for legitimacy when firms operate within a country or a region; one area that has received little attention is the situation when a firm extends its operations across borders to pursue internationalisation. The study investigates the impact of outward foreign direct investment (OFDI) on green innovation at the firm level.

Design/methodology/approach: The zero-inflated negative binomial regression models are estimated to analyse the data collected from 2065 manufacturing enterprises listed in China during 2007-2017 ( $n=14$ 129). Green innovation is measured by the number of green patents, according to the World Intellectual Property Organization (WIPO) International Patent Classification (IPC) Green Inventory.

Findings/results: The findings show that OFDI is positively associated with green innovation for emerging market enterprises (EMEs). Furthermore, compared with investment in emerging economies, OFDI in developed economies has a stronger positive relationship with corporate green innovation. The positive effect of OFDI on corporate green innovation will be higher for EMEs located in sub-national regions (i.e., province of the home country) with lower levels of institutional development.

Practical implications: Emerging market enterprises should overcome organisational inertia and compete in a broader market to enhance their awareness and ability of green innovation.

Originality/value: This article contributes to the existing literature by exploring institutional pressure faced by EMEs when they operate overseas (e.g. OFDI) can play a significant role in influencing green innovation, and enriches our understanding of EMEs' inclination towards CSR (e.g. green innovation) in the context of internationalisation.

Keywords: green innovation; outward foreign direct investment; institutional pressure; corporate social responsibility; green patent.

\section{Introduction}

Green innovation involves a process, technology or management model that can reduce energy consumption, environmental pollution and enhances corporate social responsibility (CSR) performance, which, in turn, facilitates sustainable development (Aghion, Dechezleprêtre, Hémous, Martin, \& Van Reenen, 2016). Prior research suggests that resource-seeking motivations for emerging market enterprises (EMEs) among internationalisation have an influence on product innovation and green management (Piperopoulos, Wu, \& Wang, 2018; Wang, Hong, Kafouros, \& Wright, 2012; Xia, Ma, Lu, \& Yiu, 2014). However, institutional pressure faced by EMEs during outward foreign direct investment (OFDI) decision regarding green innovation has received little attention. Indeed, firms need to achieve their economic and social goals through green governance and other CSR behaviours (Stefan \& Paul, 2008).

The existing literature has analysed the factors triggering corporate green innovation from the perspective of resource-seeking motivations in the process of internationalisation (e.g. foreign investment). Input constraints reflect the unavailability of resources such as existing competences (Perruchas, Consoli, \& Barbieri, 2020), international research and development (R\&D) network (Papanastassiou, Pearce, \& Zanfei, 2020), foreign investors (Choi, Lee, \& Williams, 2011) and government subsidy (Howell, 2017) during eco-friendly investment and innovation. Process constraints reflect the impact of internal processes and rules, such as the cultural diversity of employees in multinational firms (Chattopadhyay, George, Li, \& Gupta, 2020) and organisational decision-making styles among innovative decision (Galbreath, 2019). Output constraints focus on regulations and standards, such as local laws and regulations in their host countries (Xia, Boal, \& 
Delios, 2009) and stakeholder claims in multinational markets (Kang, 2013). However, companies may face a broader range of stakeholders and more demands among diversification and international development. Recent studies show that higher the export intensity of enterprises from developed countries, the more they pay attention to environmental management (Galbreath, 2019). In contrast to internationalisation (e.g. OFDI) of firms from developed countries, the institutional development within a transition economy is still dysfunctional and different (Shu, Zhou, Xiao, \& Gao, 2014), which may have a diverse impact on green innovation and OFDI of EMEs. The growing interest in CSR has facilitated the discussion of some other driving forces of green innovation, and there remain some areas for further exploration.

However, one area that has received little attention is the situation when a firm extends its operations across borders to pursue internationalisation (e.g. OFDI). The existing literature defines institutional pressure as threats for legitimacy or some other kind of uncertainty when firms operate within a specific organisational fields (e.g. the home country or regions) (Christmann \& Taylor, 2002; DiMaggio \& Powell, 1983), but EMEs may be expected to face a variety of demands or standards associated with green innovation when they try to run overseas. Herein, these EMEs have to conform to different formal or informal institutional practices under isomorphic effects. In this study, we extend prior research (Shu et al., 2014; Wei, Shen, Zhou, \& Li, 2015) that focus on the influence of OFDI, for Chinese EMEs by empirically demonstrating how OFDI can become beneficial to corporate green innovation. We focus on Chinese firms, as typical examples of EMEs, have gone internationalisation and competed in the developed countries (e.g. the United States and the United Kingdom) through export and OFDI; these phenomena have significantly challenged the traditional theory of international business (Dunning, 1988). Chinese EMEs will also face institutional pressures under the new environmental requirement in OFDI, which, in turn, may have an impact on green innovation and other CSR behaviour.

To bridge this gap, this study applies the numbers of green patents as the measurement of green innovation, using the sample of the Chinese listed firms in manufacturing industries, including 14129 observations from 2007 to 2017, to analyse the relationship between OFDI and green innovation. Given the important role of institutional pressure, this research answers three very important questions like, what kind of effects in strategic decisions regarding OFDI are faced by EMEs? Considering the heterogeneity of host countries in terms of institutional pressures (i.e. developed economies or emerging economies), how the location choice of the host countries moderates the focal relationship? Moreover, sub-national regions (i.e. province of the home country) differ significantly, especially for some prominent countries like China. So, how the region-specific home institutional development for EMEs moderates the relationship between OFDI and green innovation?
Our research contributes to the prior literature in several ways. Firstly, although there is evidence to reveal that corporate green innovation under the pressures of institutions varies within a country or region (Aghion et al., 2016; Shu et al., 2014), one sphere that has got little attention is the internationalisation of EMEs when they operate across the diverse economic and cultural background. The firms may face institutional differences and environmental uncertainty during the process of OFDI, which will affect their R\&D decisions. In the face of significant institutional differences, EMEs may imitate the peers in the focal industry or host country because of unfamiliarity with new social norms or legal system across the nations or culture, to reduce the risk and uncertainty (Christmann \& Taylor, 2002; Xia et al., 2009), which, in turn, triggers corporate green innovation. Our finding suggests that the institutional pressure, as well as significant difference between the home country and host country, which can trigger green innovation under the impact of isomorphic effects (DiMaggio \& Powell, 1983).

Secondly, prior studies have analysed the impact of corporate globalisation behaviours on green innovation under the background of developed economies (Galbreath, 2019), the internationalisation of developed economies to developing economies (Bu, Liu, Wagner, \& Yu, 2013; Xia et al., 2009), but the impact of the internationalisation of the EMEs from developing to developed countries under the institutional pressure concerning green innovation has been ignored in some way. Compared with developed economies, there is some difference when EMEs aim to pursuit OFDI, which, in turn, influences their behaviour of green innovation. The relationship between OFDI and green innovation is not only associated with the motivation to seek new markets or resources (Piperopoulos et al., 2018; Wang et al., 2012), but it also exposes these EMEs to varying institutional pressure in OFDI, which later provides competitive advantages and chances to transfer knowledge to the home country. As the largest transition economy in the world, China has strengthened its economy through the 'going out' policy. Many Chinese firms are trying to find new markets or resources through foreign direct investment, which has an impact on social responsibility behaviours such as green innovation and also provides an excellent research situation. Exploring the internationalisation of Chinese enterprises from the perspective of institutional pressure does not only extend the existing theories but also provide some implications for EMEs to 'go out' further. Our finding reveals that location choice (i.e. developed or emerging countries) and region-specific home institutional development can moderate the relation between OFDI and corporate green innovation.

Thirdly, compared to existing research, this article directly uses the number of green patents at the firm level to measure green innovation performance. Compared to the use of survey interviews (Galbreath, 2019), environmental investment (Stucki, 2019) and third-party rating scores (Kang, 2013; Luo, Wang, \& Zhang, 2017), green patents at the firm level are more objective and reflect the willingness 
and ability of corporate innovation to pursue environmental protection.

\section{Background and hypotheses development \\ The context of corporate green innovation}

With the emergence of sustainable development, firms will face a variety of stakeholders' demands while responding to them through CSR behaviours (e.g. green management) that environmental regulation can stimulate companies to innovate. Recent research has begun to explore how companies can innovate in a variety of constraints. For example, carbon trading (Aghion et al., 2016), regulation of industrial emissions (Popp, 2006) and appeals of diverse stakeholders (e.g. customers and employees) will promote their R\&D investment (Kang, 2013). Innovation is performed under the internal and external environment, which is a response to various constraints (Acar, Tarakci, \& Knippenberg, 2019).

Institutional theory is a reasonable explanation for the motives of CSR behaviours such as corporate green innovation and organisational behaviour that depends on its interaction with the external environment. Coercive isomorphism, mimetic isomorphism and normative isomorphic pressures affect the innovation activities of enterprises in a particular organisational field, according to institutional requirements (DiMaggio \& Powell, 1983). Firstly, the impact of coercive isomorphism on corporate behaviour is most pronounced. Emerging market enterprises are often influenced by government motives (Fabrizi, Guarini, \& Meliciani, 2018) and various industrial policies. For example, multinational firms have to apply local environmental standard to meet the host countries' law. Secondly, in the face of uncertainty, firms may imitate their peers (e.g. the trend of green packing in EU region) under the effect of mimetic isomorphism. Finally, social norms and expectations will influence the willingness of enterprises to innovate. A firm may achieve the goal of technological catchup under the impact of normative isomorphism and diversified culture background. These stakeholders will influence the behaviour of the company through trade and competition, including the company's investors, consumers, suppliers and competitors (Kang, 2013).

Prior studies reveal the influence of institutional changes on corporate environmental management behaviours within a nation or a region, such as changes in laws and regulations for local community (Christmann \& Taylor, 2002; Xia, Tan, \& Tan, 2008), changes in social norms within single culture background (Fabrizi et al., 2018; Popp, 2006) and diversity of stakeholders. Indeed, the survival and development of enterprises in a specific organisational field, along with the uncertainty brought by institutional changes, pose a threat to the legitimacy of enterprises. To make a balance between legitimacy and efficiency, multinational firms have to comply with local norms, practices or regulations of a country, which explains some strategic change and some phenomenon of diffusion. In contrast, when firms operate within the home country and another overseas nation (i.e. host countries) through OFDI, they will face more considerable institutional differences and environmental uncertainties. Especially for EMEs, which are young and lack the experience to adapt to different institutional and cultural settings, will face more threats of legitimacy or survival caused by substantial institutional differences, which, in turn, lead to some isomorphic behaviours (e.g. green innovation) (DiMaggio \& Powell, 1983). In this context, institutional pressure is believed to be a source of motivation for corporate green innovation or some other CSR behaviours among internationalisation.

\section{Outward foreign direct investment of emerging market enterprises and green innovation}

Innovation is risky and long-term oriented, especially green innovation. When EMEs extend their operations from their home country to host countries, the environment they face will be more complicated, which is a threat and an opportunity for green innovation. Only when the marginal benefit of green innovation exceeds its marginal cost, the specific organisational behaviour continues to spread under the effect of isomorphism (Stefan \& Paul, 2008; Stucki, 2019). This article argues that OFDI of EMEs may enhance green innovation for three aspects:

Firstly, OFDI facilitates EMEs to operate in a variety of organisational fields across nations, which is expected to improve the existing technologies, processes or standards associated with green innovation. On the one hand, study of international market entry strategies argues that, when developed countries' enterprises enter the emerging countries (Xia et al., 2009) or internationalisation of enterprises from the neighbouring developed economies (Galbreath, 2019) or the internationalisation between two emerging countries (Wang et al., 2012), they will face the problem of 'liability of foreignness' (Zaheer, 1995). Especially for EMEs that lack comparative advantage, they will be prone to feel the pressure of new institutional expectations in international competition. Mandatory isomorphic pressures from governments, trade unions and industry associations, especially in the face of excessive concerns caused by host country 'outsider threats' (Johanson \& Vahlne, 2009), will allow companies to pay more attention to their environmental responsibilities in foreign direct investment. As the concept of sustainable development is widely accepted in all countries, along with Kyoto Protocol at the end of the last century, Paris climate agreement, and CSR actions in recent decades (Arora, Kourula, \& Phillips, 2019), green innovation has become an essential way for 'outsiders' to increase their legitimacy (Galbreath, 2019; Shu et al., 2014). On the contrary, green innovation involves the changes in existing processes or standards, which will break the inertia of the firms. Directly driven by mandatory isomorphic pressure, the marginal benefits of green innovation will gradually increase; otherwise, these firms will face penalties or barriers (Papanastassiou et al., 2020). 
In addition, OFDI also offers EMEs with more opportunities to absorb new knowledge and serves as 'learning laboratories' for EMEs (Perruchas et al., 2020). Institutional pressures in the host country may impose requirements on corporate environmental standards or absorbing new knowledge in interaction with international supply chains, new consumers and new regulatory policies from the social network (Xing, Xia, \& Guo, 2019), which help EMEs to enhance green innovation.

Secondly, EME's subsidiaries have to conform to diverse institutional environment through imitation or learning, which will benefit from the spill over of the eco-friendly technology or knowledge. Emerging market enterprises are highly uncertain about their OFDI because of formal institutional differences such as legal and regulatory policies (Bu et al., 2013; Lee, Veloso, \& Hounshell, 2011), or informal institutional differences, such as diverse cultures and customs (Chattopadhyay et al., 2020). On the one hand, EMEs facing uncertainty during OFDI may rely on social comparison or inter-organisational mimetic isomorphism from the same industry or region (Kumar \& Zaheer, in press) under the effects of mimetic isomorphism. To reduce the threat of legitimacy, when they face external regulation in the developed economies, they can reduce risks by adopting the new standards or model in environmental management associated with green technologies to adapt to the supply chain (Xing et al., 2019), consumer markets (Shu et al., 2014) or other organisations' demands (Stefan \& Paul, 2008). With the emergence of sustainable development, governments, associations and enterprises are generally concerned about the low-carbon economy and corporate environmental responsibility. On the other hand, even if EMEs as foreign competitors operate abroad in developing countries, their social responsibility performance (e.g. environment standard and consumer right) will be concerned by the local government or other NGOs. For example, an OFDI project invested by Chinese firms - Songshui Power Station in Burma - had been considered as a threat to local environment. Emerging market enterprises are driven by bandwagon effect (Abrahamson \& Rosenkopf, 1993; Xia et al., 2008) to reduce the risk of being an 'outsider' by mimetic isomorphism and absorption of green technologies. In addition, the 'economies of scale' (Kang, 2013) along with OFDI or other globalisation activities have also reduced the risk of technological innovation and created conditions for the transformation of green technologies (Perruchas et al., 2020). Therefore, if enterprises want to reduce the risk of OFDI, it is necessary to understand the difference between the formal and the informal institutional environment of the host country. If EMEs can wisely respond to these institutional differences and utilise the conditions of 'economies of scale', they will be able to adapt to a variety of environments as a 'learning laboratories' for green innovation.

Thirdly, OFDI allows EMEs to respond to diverse stakeholders' demands by integrating and employing green technologies while fostering competitive advantages. On the one hand, the level of EMEs' international diversification is also related to the number of stakeholders (Arora et al., 2019) and the demands of stakeholders (e.g. employees and regulators). Green innovation is the effective mean of responding to stakeholder demands and forming competitive advantages when faced with threats from potential entrants and existing competitors. On the other hand, with the diffusion of the concept of sustainable development, consumers, employees and industry associations have begun to pay attention to CSR and gradually embed in social norms of the region. To enhance the organisational identity of each employee, EMEs need to demonstrate their focus on environmental responsibility and promote green innovation. Flammer and Kacperczyk (2019) find that firms committed to CSR such as green technologies can prevent technology leaks because it increases employee loyalty. In addition, EMEs will face more and more consumers, suppliers and companies in the same industry with the development of OFDI (Kumar \& Zaheer, 2020), which will encourage firms to focus on green innovation to meet diverse industry and market regulations. Therefore, as the scope of OFDI continues to expand, EMEs need to respond to these diverse stakeholder demands, providing a pleasant internal environment for green innovation when fostering competitive advantages. Hence, we propose:

H1: OFDI of EMEs is positively associated with corporate green innovation.

\section{The moderate effect of the location choice}

Although OFDI confronts EMEs to face institutional pressure, which, in turn, triggers green innovation. However, the location choice of the host countries (developed countries or emerging countries) also plays a vital role and moderates the focal relationship. Indeed, innovation nourishes in different institutional contexts (Wang, Yi, Kafouros, \& Yan, 2015). Firstly, compared with investment in emerging countries, developed countries have better regulations and legal systems with stronger coercive pressure for corporate green innovation. Only when markets and related rules can provide the proper resources, firms can respond to the appeals of many audiences (i.e. stakeholders) effectively and immediately (Arora et al., 2019). Developed countries have a more robust legal and regulatory system than developing countries (Li, Strange, Ning, \& Sutherland, 2016), along with some well-developed knowledge network and market order, which provides a guarantee for corporate environmental management and R\&D. At the same time, the perfect system of developed countries puts forward higher requirements for products and services associated with green innovation under the pressure of environmental supervision and industry norms. In addition, the different needs and fierce competition make EMEs adapt to the environment through environmental-friendly technologies or products within a developed market. The competition in product market requires enterprises to form competitive advantages, which requires EMEs to adapt to external environment through green innovation. 
Secondly, the effect of isomorphism of developed countries is greater than OFDI in developing countries. When companies operate beyond their home countries, they will face greater institutional differences and severe institutional pressure (Kumar \& Zaheer, 2020). Under the strict environmental regulation from local government and environmental concerns of society in developed countries, EMEs will follow local companies through adapting green innovation to acquire efficiency, such as improving existing industries, processes and standards under the bandwagon effects. For EMEs, the institutional differences between their home countries and developed countries (i.e. host countries) are even more significant along with the lack of comparative advantage in international competition. Emerging market enterprises will face higher institutional pressure in terms of OFDI in developed economies as compared to emerging economies, which motivate them to improve their legitimacy by green innovation. In addition, compared with the imperfect institutional background and market environment of emerging countries (Wei et al., 2015), OFDI in developed countries provides some opportunities to interact and imitate the local enterprises and cooperate with them to form the green technology R\&D network (Fabrizi et al., 2018; Xing et al., 2019), which becomes a necessary condition for the emergence and acceptance of green innovation.

Thirdly, compared with developing countries, stakeholders in developed countries are more concerned about environmental responsibility, and the normative isomorphic pressure of green innovation is greater. Some developing countries have become 'pollution paradise' in pursuit of economic growth (Bu et al., 2013; Levinson \& Taylor, 2008), and it is difficult to provide a good external environment for green innovation. When EMEs invest in developed countries, the government, industry associations and the public have higher requirements for eco-environmental protection requirements for products and services. Local residents and employees are more concerned about green management in the production and circulation of enterprises (Shu et al., 2014). This creates internal and external pressure for corporate green innovation. In addition, the research and application of green technology by scientific research institutions, supply chains and even peer firms in developed countries form a normative pressure for green innovation (Xing et al., 2019). Hence, we propose:

H2: The positive effect of OFDI on corporate green innovation will be stronger for OFDI in developed countries than OFDI in emerging countries.

\section{The moderate effect of the region-specific home institutional development}

In addition to the location choices of OFDI from the hostcountry perspective, the region-specific home institutional development may moderate the focal relationship. Subnational regions (i.e. province of the home country) in emerging countries may differ significantly, especially for some typical countries like China. Some EMEs may be located in the region of their countries with diverse levels of institutional development, which may moderate the relation between OFDI and corporate green innovation.

Firstly, if EMEs are located in regions with a relatively lower degree of institutional development in their home countries, the institutional differences will be more significant when they enter the international market through OFDI, which will make them more sensitive to the effects of isomorphic pressure (Xia et al., 2008). These EMEs have more motivation to improve existing production processes and products through green innovation to get efficiency through OFDI, have analysed that EMEs suffer from institutional constraints are more likely to 'escape' from their home country through OFDI, which will make them pay more attention to institutional differences and improve their green technologies or product standards legality. In addition, OFDI seeks new markets and new opportunities for EMEs (Wang et al., 2012). Emerging market enterprises from less developed regions need to adapt to various normative pressures, such as environmental management, through green innovation to meet the broader stakeholders.

Secondly, when the region-specific home institutional development is relatively higher, the local better institutional systems, market operation and social norms altogether make EMEs more adaptable to the institutional environment in OFDI, which, in turn, alleviates the institutional differences between the home country and the host country $(\mathrm{Li}, \mathrm{Li}, \&$ Shapiro, 2012). If EMEs operate in a good institutional environment before OFDI, the pressure caused by the differences in the system will be greatly reduced, and the possibility of new mimetic isomorphism will also be reduced. In addition, the degree of institutional development of the home country and the impact of OFDI on green investment have a substitution effect. The better the institutional environment in the home country, the more capable and efficient the EMEs will be when facing fierce market competition and diverse stakeholders in the host country ( $\mathrm{Xu}$, Zhou, \& Du, 2019). Moreover, EMEs are gradually embedded in the green technology network of the home region with a better institutional environment (Batjargal et al., 2013; Russo \& Perrini, 2009), which will rely less on OFDI to promote green innovation performance. Hence, we propose:

H3: The positive effect of OFDI on corporate green innovation will be higher for firms are headquartered in sub-national regions with lower levels of institutional development.

\section{Method \\ Sample and data}

To test our hypotheses, we develop a unique panel dataset of Chinese manufacturing firms listed in the A-share of Shanghai Stock Exchange and Shenzhen Stock Exchange from 2007 to 2017. We begin our investigation with 2007 because Chinese listed companies have implemented the new accounting standards and disclosure corporate investment information (e.g. foreign subsidiaries) compulsorily since 2007. The sample of this article includes 
14129 firm-year observations for 2065 companies. The financial data are obtained from the China Stock Market Accounting Research Database (CSMAR). STATA 15.1 software is used to analyse the data.

\section{Dependent variables}

Following prior studies (Aghion et al., 2016; Fabrizi et al., 2018), Green Innovation is measured by the number of green patents a firm has been granted in a given year, which may have an association with environmentally friendly technology, energy-saving technology and sustainable development (Aghion et al., 2016).

The original data of the patents are mainly collected from the database of State Intellectual Property Office of China (SIPO) manually, and the handling process is as follows. Firstly, we collect the exact name of the parent company and all its subsidiaries as the patent applicant from the annual reports of that firm. Secondly, the patent information of each firm is collected from the database of SIPO (www.pss-system.gov. $\mathrm{cn}$ ), including the date of application, date of publication, the application number, publication number, inventor, applicant, patent classification number (IPC), authorisation status and the number of citations. Finally, we judge whether the patent is a green patent (i.e. environmentally sound technologies), according to the IPC Green Inventory issued by the World Intellectual Property Organization (www.wipo.int/ classifications/ipc/en/green_inventory), which contains almost 200 topics (IPC numbers of the patents) that are directly relevant to clean technologies (Aghion et al., 2016; Fabrizi et al., 2018).

\section{Independent variables}

Overall investment in foreign countries is calculated by the ratio of the total amount (value) of OFDI to total investment of each firm (Liu, Lu, \& Chizema, 2014; Piperopoulos et al., 2018; Wang et al., 2012), which reflects the actual amount of annual overseas investment undertaken by each firm. The use of this ratio to measure OFDI can help to control the size of firms (Lev \& Sunder, 1979; Piperopoulos et al., 2018). In addition, OFDI is further divided into Investments in developed countries and Investments in emerging countries according to World Bank standards (data.worldbank.org/income-level/ high-income) to consider the location choice for each firm.

Region-specific home institutional development is measured by the sub-dimension of the National Economic Research Institute (NERI) index on market intermediaries' development and law enforcement for the region a firm is headquartered in (Wu, Wang, Hong, Piperopoulos, \& Zhuo, 2016). We collected the headquarters' location from annual reports of the firms and used the sub-dimension of the NERI index to measure institutional development in different regions (Huang \& Li, 2019; Xu et al., 2019). The China Marketisation Index issued by the NERI includes the relationship between the government and the market, the development of non-state-owned economy, product market, factor market, intermediary organisation and legal protection. It reflects the institutional development in the region and had been widely used in the study of the Chinese companies' behaviour (Gao, Murray, Kotabe, \& Lu, 2009; Xie \& Li, 2017; Xu et al., 2019).

\section{Control variables}

We also include some control variables. Firm size is calculated by the natural logarithm of the number of employees $(\mathrm{Xu}$ et al., 2019). Firm age is measured by the number of years since the establishment of the company (He \& Tian, 2013). Large enterprises have resources to carry out R\&D and innovation activities because of their more resources and risk-taking capabilities, while firm age reflected its growth stage. Leverage is measured by total debt divided by total assets (Conyon, He, \& Zhou, 2015). Return on assets (ROA) is measured by return on the total assets (Wang et al., 2012). We also control the firm's growth opportunities using Tobin $Q$, which is calculated as the market value of a company divided by the replacement cost of the asset (Sunder, Sunder, \& Zhang, 2017). RED intensity reflects the willingness and ability of technological innovation and is equal to the ratio of R\&D expenses divided by sales (Piperopoulos et al., 2018). State ownership is equal to the ratio of state-owned capital over total capital. Board size is measured by the total number of board members (Liu et al., 2014). Market competition is measured by the sum of squares of the percentages of sales of the focal firm in each industry. In addition, we add industry dummy variables and year dummy variables.

\section{Model}

As the dependent variable, green innovation is measured by the number of green patents for a firm, which may indicate over-dispersion issue (Cameron \& Trivedi, 2005; Piperopoulos et al., 2018). The Negative Binomial model, as a kind of the count model, can be used in our research, which is suitable for addressing this issue (Karkinsky \& Riedel, 2012). However, Vuong test $(Z=2.25, p=0.01)$ suggests that the dependent variable has an excessive number of zero values, while standard Negative Binomial model models are not able to handle the presence of excess zero counts (Xia et al., 2014). To deal with the situation, Zero-inflated Negative Binomial regression (ZINB) model can be a better estimation technique for our analysis (Cornaggia, Mao, Tian, \& Wolfe, 2015; Seru, 2014; Sunder et al., 2017). Following Xia et al.'s (2014) procedure to apply the Vuong test, we use the ZINB model (command: zinb) in Stata 15.1 to analyse the data in our research. We also lag all the explanatory variables by 1 year to deal with the endogeneity problem.

\section{Results \\ Descriptive statistics and correlations}

Table 1 reports the descriptive statistics of the variables. The mean value of the overall investment in foreign countries is 
TABLE 1: Descriptive statistics and correlations $(N=14129)$

\begin{tabular}{|c|c|c|c|c|c|c|c|c|c|c|c|c|c|c|c|c|}
\hline Variable & Mean & SD & 1 & 2 & 3 & 4 & 5 & 6 & 7 & 8 & 9 & 10 & 11 & 12 & 13 & 14 \\
\hline 1. Green innovation & 2.93 & 18.97 & 1 & - & - & - & - & - & - & - & - & - & - & - & - & - \\
\hline 2. Overall investment in foreign countries & 0.07 & 0.23 & 0.08 & 1 & - & - & - & - & - & - & - & - & - & - & - & - \\
\hline 3. Investment in developed countries & 0.06 & 0.19 & 0.04 & 0.92 & 1 & - & - & - & - & - & - & - & - & - & - & - \\
\hline 4. Investment in emerging countries & 0.01 & 0.05 & 0.09 & 0.47 & 0.15 & 1 & - & - & - & - & - & - & - & - & - & - \\
\hline 5. Region-specific home institutional development & 8.24 & 4.59 & 0.05 & 0.08 & 0.09 & 0.02 & 1 & - & - & - & - & - & - & - & - & - \\
\hline 6. Firm size & 7.60 & 1.23 & 0.18 & 0.08 & 0.07 & 0.08 & -0.06 & 1 & - & - & - & - & - & - & - & - \\
\hline 7. Firm age & 16.82 & 5.58 & 0.06 & 0.04 & 0.04 & 0.01 & 0.12 & 0.10 & 1 & - & - & - & - & - & - & - \\
\hline 8. Leverage & 0.41 & 0.22 & 0.07 & 0.01 & -0.01 & 0.06 & -0.21 & 0.33 & 0.11 & 1 & - & - & - & - & - & - \\
\hline 9. ROA & 0.04 & 0.07 & 0.01 & 0.01 & 0.02 & -0.01 & 0.12 & 0.04 & -0.08 & -0.45 & 1 & - & - & - & - & - \\
\hline 10. Tobin Q & 3.20 & 2.27 & -0.06 & 0.00 & 0.00 & -0.02 & 0.08 & -0.41 & 0.02 & -0.24 & 0.15 & 1 & - & - & - & - \\
\hline 11. $R \& D$ intensity & 0.03 & 0.05 & 0.04 & 0.04 & 0.05 & 0.00 & 0.17 & -0.13 & 0.00 & -0.23 & 0.03 & 0.13 & 1 & - & - & - \\
\hline 12. State ownership & 0.06 & 0.14 & 0.01 & -0.04 & -0.04 & -0.02 & -0.22 & 0.13 & -0.14 & 0.14 & -0.05 & -0.07 & -0.10 & 1 & - & - \\
\hline 13. Board size & 2.27 & 0.24 & 0.05 & 0.01 & 0.00 & 0.03 & -0.05 & 0.21 & 0.11 & 0.16 & -0.08 & -0.10 & -0.05 & 0.08 & 1 & - \\
\hline 14. Market competition & 0.08 & 0.07 & -0.01 & -0.01 & -0.01 & 0.00 & -0.06 & 0.09 & -0.05 & 0.10 & -0.03 & -0.10 & -0.13 & 0.05 & 0.01 & 1 \\
\hline
\end{tabular}

SD, standard deviation; ROA, return on assets; R\&D, research and development.

0.07 , with a standard deviation of 0.23 , which means the average proportion of OFDI in total investment is $7 \%$ for Chinese listed manufacturing firms. Consistent with the existing prediction (Liu et al., 2014; Piperopoulos et al., 2018), we find the mean value of Investment in developed countries is 0.06 , which is higher than the mean value of Investment in emerging countries. The mean value of the dependent variable, green Innovation, is 2.93, while the standard deviation is 18.97 , which means the average number of green patents is 2.93 for Chinese listed manufacturing firms. All correlations are relatively low. We also calculate variance inflation factors (VIFs) and find that all VIFs are below 10.

\section{Regression analysis}

Table 2 reports the results. Model 1 includes the main explanatory variable, Overall investment in foreign countries, and control variables, serving as the baseline model. Model 2 includes all the variables including moderate variable; the coefficient of Overall investment in foreign countries (0.316) is still positive and significant at $1 \%$ level, which means that OFDI is positively associated with corporate green innovation and supports H1. Overall, when EMEs pursue international development (i.e. OFDI, a typical way of entering international markets), they will pay more attention to social goals (Shu et al., 2014) among diversified regulation demand and stakeholders' claims (Kang, 2013). Specifically, a rise of $1 \%$ in the proportion of OFDI in total investment is associated with $0.316 \%$ increases in the number of green patents (green innovation), suggesting that our findings are meaningful in explaining corporate green innovation.

To test $\mathrm{H} 2$, in model 3, the coefficients of investment in developed countries (0.338) is positive and significant at $5 \%$ level, while coefficients of investment in emerging countries (0.313) is positive but not significant, lending support for $\mathrm{H} 2$, which predicts that the positive effect of OFDI of EMEs on corporate green innovation will be stronger for OFDI in developed countries than OFDI in emerging countries. Specifically, a rise of $1 \%$ in the proportion of OFDI in developed countries in total investment is associated with
$0.338 \%$ increases in the number of green patents (green innovation). Because of diversity in host countries, the positive effect of OFDI on green innovation is more likely to be observed for OFDI in developed countries, and location choice of OFDI becomes contingency to discuss focal relationship.

To test H3, interaction variables are mean-centred to minimise potential multicollinearity (Xia et al., 2014). As the results in model 4 , the coefficient of the interaction term, Overall investment in foreign countries $\times$ Region-specific home institutional development (-0.077), is negative and significant, lending support for $\mathrm{H} 3$, which predicts that the positive effect of OFDI of EMEs on corporate green innovation will be higher for firms headquartered in sub-national regions with lower levels of institutional development. As shown, the positive effect of OFDI is more significant when EMEs from the region of lower levels of institutional environment that significant institutional difference in OFDI will create more pressure on green innovation under the effect of isomorphism forces (Xia et al., 2008).

We further analyse the moderate effect of institutional development on the relationship between OFDI in developed or emerging countries and green innovation, respectively. As the results in model 5, the coefficient of the interaction term, Investment in developed countries $\times$ Region-specific home institutional development (-0.114), is still negative and significant but another interaction term, Investment in emerging countries $\times$ Region-specific home institutional development (0.081), is positive and not significant, which further supports $\mathrm{H} 3$.

\section{Robust test}

Firstly, we measure green innovation performance by the citations of green patents the firm has received. The prior research (He \& Tian, 2013; Jia, Huang, \& Man Zhang, 2019) regard the citation number of patents for each firm as the quality and commercial value of innovation. The results (panel A of Table 3) are still robust. 
TABLE 2: The analysis of outward foreign direct investment and green innovation ( $N=14$ 129).

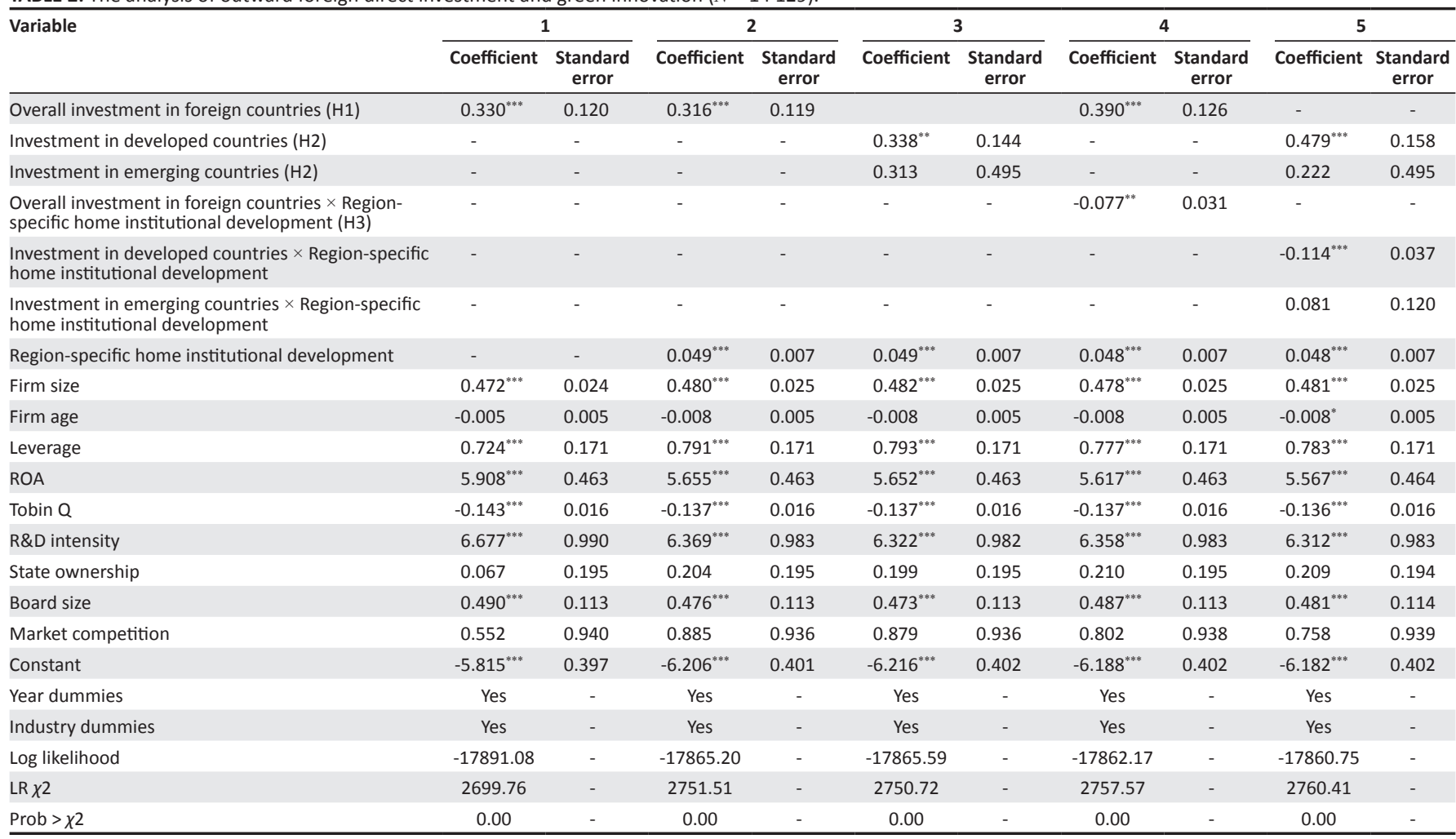

ROA, Return on assets; R\&D, research and development; $x$, multiplication sign.

$*, p<0.10 ; * *, p<0.05 ; * * *, p<0.01$.

Secondly, we measure of OFDI by the dummy. Dummy_ Overall investment in foreign countries is equal to 1 if the company has invested in a foreign country, and 0 otherwise. Similarly, investment in developed countries and investment in developing countries are also measured by their respective dummy variables. The results are shown in panel B of Table 3 , and the results are still consistent with the previous finding.

Thirdly, we use the lawyer density to measure the regionspecific home institutional development (panel C in Table 3) according to the existing research (Huang, Ma, Yang, \& Zhang, 2016; Van Waarden, 2001; Xie \& Li, 2017). We calculate lawyer density by using the ratio of the number of practicing lawyers in each province divided by the total population (10 000 people). The data are collected from the annual statistical book of the judicial departments of the provinces. The regional lawyer density reflected the degree of regional legal protection and had an impact on corporate innovation and the quality of international trade (Huang et al., 2016), which is related to institutional development in a region.

Fourthly, the firm's investment in 'tax havens' (such as the British Virgin Islands, British Jersey, Cayman Islands, US Virgin Islands, Bermuda, etc.) may include tax avoidance motives. The inspection is re-measured in accordance with OECD standards to exclude OFDI in 'tax havens' (Hampton \& Christensen, 2002; Lu, Liu, Wright, \& Filatotchev, 2014). The results are shown in panel D of Table 3 and the regression results are basically consistent, indicating that the above results are more robust.
Fifthly, we exclude samples of state-owned enterprises (SOEs) and only use the sample of private firms to analyse. Private enterprises may be more susceptible to institutional pressure than SOEs when they try to invest in foreign countries (Wang et al., 2015). The results suggest that the relationship between OFDI and green innovation and the moderate effects are still significant for private firms.

Finally, the issue of endogeneity might arise (e.g. more innovative firms choose to invest in foreign countries) in our analysis. We used a 1-year lag of overall investment in foreign countries, as instrumental variable (IV) while adopting a two-stage procedure to test the potential endogeneity. In the first stage, we regressed all potential instruments and all exogenous variables. In the second stage, we estimated the models by using the predicted values of the possible endogenous variable (Piperopoulos et al., 2018; Wang et al., 2012). After the Hausman test, the results showed that Chisquare is 0.00 while $p$-value is 1.00 , which cannot reject the null hypothesis that the difference in coefficients is not systematic. We also use ordinary GMM method, using the logarithm of the green innovation performance (the number of green patents) plus 1 as the dependent variable, the results are still robust.

\section{Conclusion}

Although scholars always conceptualise that green innovation may occur under the institution within a country or region, one sphere that has got little attention is the internationalisation of EMEs (i.e. operation across the 


\begin{tabular}{|c|c|c|c|c|c|c|c|c|}
\hline \multirow[t]{2}{*}{ Variable } & \multicolumn{2}{|c|}{ (1) } & \multicolumn{2}{|c|}{ (2) } & \multicolumn{2}{|c|}{ (3) } & \multicolumn{2}{|c|}{ (4) } \\
\hline & Coefficient & $\begin{array}{l}\text { Standard } \\
\text { error }\end{array}$ & Coefficient & $\begin{array}{l}\text { Standard } \\
\text { error }\end{array}$ & Coefficient & $\begin{array}{l}\text { Standard } \\
\text { error }\end{array}$ & Coefficient & $\begin{array}{l}\text { Standard } \\
\text { error }\end{array}$ \\
\hline \multicolumn{9}{|l|}{ Panel A: Number of the citations of green patents as the dependent variable } \\
\hline Investment in developed countries & - & - & $0.629^{* *}$ & 0.280 & - & - & $0.896^{* * *}$ & 0.318 \\
\hline Investment in emerging countries & - & - & -0.227 & 0.906 & - & - & -0.422 & 0.894 \\
\hline $\begin{array}{l}\text { Overall investment in foreign countries } \times \text { Region-specific home institutional } \\
\text { development }\end{array}$ & - & - & - & - & $-0.146^{* *}$ & 0.065 & - & - \\
\hline Investment in developed countries $\times$ Region-specific home institutional development & - & - & - & - & - & - & $-0.226^{* * * *}$ & 0.079 \\
\hline Investment in emerging countries $\times$ Region-specific home institutional development & - & - & - & - & - & - & 0.111 & 0.203 \\
\hline Region-specific home institutional development & $0.081^{* * * *}$ & 0.013 & $0.080^{* * * *}$ & 0.013 & $0.078^{* * *}$ & 0.013 & $0.076^{* * *}$ & 0.013 \\
\hline Log likelihood & -8737.555 & - & -8736.514 & - & -8734.968 & - & -8732.215 & - \\
\hline $\operatorname{LR} \chi 2$ & 1619.66 & - & 1621.75 & - & 1624.84 & - & 1630.34 & - \\
\hline Prob $>\chi 2$ & 0.00 & - & 0.00 & - & 0.00 & - & 0.00 & - \\
\hline \multicolumn{9}{|l|}{ Panel B: Measure OFDI as a dummy variable } \\
\hline Dummy_Investment in developed countries & - & - & $0.211^{* * * *}$ & 0.061 & - & - & $0.233^{* * *}$ & 0.062 \\
\hline Dummy_Investment in emerging countries & - & - & $0.340^{* * * *}$ & 0.090 & - & - & $0.334^{* * * *}$ & \\
\hline $\begin{array}{l}\text { Dummy_Overall investment in foreign countries } \times \text { Region-specific home institutional } \\
\text { development }\end{array}$ & - & - & - & - & $-0.041^{* * * *}$ & 0.013 & - & - \\
\hline $\begin{array}{l}\text { Dummy_Investment in developed countries } \times \text { Region-specific home institutional } \\
\text { development }\end{array}$ & - & - & - & - & - & - & $-0.045^{* * *}$ & 0.014 \\
\hline $\begin{array}{l}\text { Dummy_Investment in emerging countries } \times \text { Region-specific home institutional } \\
\text { development }\end{array}$ & - & - & - & - & - & - & 0.002 & 0.021 \\
\hline Region-specific home institutional development & $0.045^{* * * *}$ & 0.007 & $0.045^{* * * *}$ & 0.007 & $0.060^{* * * *}$ & 0.008 & $0.059^{* * * *}$ & 0.008 \\
\hline Log likelihood & -17860.45 & - & -17852.41 & - & -17855.5 & - & -17847.12 & - \\
\hline $\operatorname{LR} \times 2$ & 2761.01 & - & 2777.09 & - & 2770.91 & - & 2787.67 & - \\
\hline Prob $>x 2$ & 0.00 & - & 0.00 & - & 0.00 & - & 0.00 & - \\
\hline \multicolumn{9}{|l|}{ Panel C: Measure Region-specific home institutional development as Lawyer density } \\
\hline Overall investment in foreign countries & $0.341^{* * *}$ & 0.118 & - & - & $0.370^{* * *}$ & 0.121 & - & - \\
\hline Investment in developed countries & - & - & $0.351^{* *}$ & - & - & - & $0.388^{* * *}$ & 0.147 \\
\hline Investment in developed countries $\times$ Lawyer density & - & - & - & - & - & - & -0.092 & 0.057 \\
\hline Investment in emerging countries $\times$ Lawyer density & - & - & - & - & - & - & -0.216 & 0.239 \\
\hline Lawyer density & $0.078^{* * * *}$ & 0.010 & $0.078^{* * * *}$ & 0.010 & $0.077^{* * *}$ & 0.010 & $0.077^{* * *}$ & 0.010 \\
\hline Log likelihood & -17859.43 & - & -17859.85 & - & -17857.51 & - & -17858.11 & - \\
\hline $\operatorname{LR} \chi 2$ & 2763.05 & - & 2762.21 & - & 2766.89 & - & 2765.70 & - \\
\hline Prob $>\chi 2$ & 0.00 & - & 0.00 & - & 0.00 & - & 0.00 & - \\
\hline \multicolumn{9}{|l|}{ Panel D: Excluding OFDI in 'Tax havens' zones } \\
\hline Overall investment in foreign countries & $0.308^{* *}$ & 0.122 & - & - & $0.381^{* * *}$ & 0.129 & - & - \\
\hline Investment in developed countries & - & - & $0.335^{* *}$ & 0.151 & - & - & $0.478^{* * *}$ & 0.165 \\
\hline Investment in emerging countries & - & - & 0.325 & 0.494 & - & - & 0.243 & 0.495 \\
\hline $\begin{array}{l}\text { Overall investment in foreign countries } \times \text { Region-specific home institutional } \\
\text { development }\end{array}$ & - & - & - & - & $-0.079^{* *}$ & 0.031 & & \\
\hline Investment in developed countries $\times$ Region-specific home institutional development & - & - & - & - & - & - & $-0.120^{* * * *}$ & 0.038 \\
\hline Investment in emerging countries $\times$ Region-specific home institutional development & - & - & - & - & - & - & 0.080 & 0.120 \\
\hline Region-specific home institutional development & $0.049^{* * *}$ & 0.007 & $0.049^{* * *}$ & 0.007 & $0.048^{* * *}$ & 0.007 & $0.048^{* * *}$ & 0.007 \\
\hline Log likelihood & -17865.58 & - & -17865.93 & & -17862.46 & - & -17860.83 & - \\
\hline $\operatorname{LR} \chi 2$ & 2750.76 & - & 2750.06 & & 2756.99 & - & 2760.25 & - \\
\hline Prob $>\chi 2$ & 0.00 & - & 0.00 & & 0.00 & - & 0.00 & - \\
\hline
\end{tabular}

Note: The control variables are included but not shown for saving space.

OFDI, outward foreign direct investment.

$*, p<0.10 ; * *, p<0.05 ; * * *, p<0.01$.

diverse economic and cultural background). Based on the samples of China A-share listed manufacturing companies from 2007 to 2017, the results support our framework by showing that OFDI of EMEs is positively associated with green innovation, indicating that a link between OFDI and corporate green innovations for EMEs. The positive effect of OFDI on green innovation is more likely to be observed for OFDI in developed countries than OFDI in emerging countries. The region-specific home institutional development will moderate the focal relationship, which suggests the positive effect of OFDI on corporate green innovation will be stronger when EMEs are headquartered in sub-national regions with lower levels of institutional development. The research supports the institutional pressure hypothesis of green innovation, which helps to understand the motives of CSR behaviours. 


\section{Implication}

This study extends previous theoretical perspectives of institutional theory and sheds lights on motivation for green innovation from the emerging economies and EMEs perspective. It has been suggested in prior literature that green innovation may be influenced by the institutional environment within a single country or region (Shu et al., 2014; Wei et al., 2015). However, the research finds that except for local institutional environment of the home country, as the boundaries of business operations for EMEs continue to expand (e.g. OFDI), the external environment (i.e. foreign markets) faced by EMEs may expose firms to new kinds of institutional pressures. That is, OFDI makes EMEs face pressure from their host countries (Xia et al., 2009), new stakeholders and new supply chains. When EMEs interact with overseas diverse organisational environment, they may face new institutional pressures, which may come from coercive forces (e.g. government environmental regulation) and mimetic isomorphism forces (e.g. peer companies in the supply chain) and the normative forces (e.g. ethical standards), these will form a new external environment of green innovation. Therefore, this study suggests that institutional pressure is also likely to come from the international organisation field (i.e. host country), which may be distinct from the home country of a firm.

While the pressures of coercive isomorphism, mimetic isomorphism and normative isomorphism can spur green innovation, we find that the choice of the host country (i.e. OFDI in developed or emerging countries) will moderate the relationship between OFDI and green innovation. Developed countries have a perfect institutional environment, which creates incentives and bases for green innovation for globally operated enterprises. As a host country, greater institutional differences can encourage enterprises to carry out green innovation based on the pressure of mimetic isomorphism effects; diverse stakeholders appeals and a broad market not only encourage companies to innovate green but also diversify the risks of innovation through economies of scale (Kang, 2013). Therefore, EMEs should enhance their environmental management capabilities (e.g. green innovation) and sense of responsibility through an international competition, and reverse absorption through interaction with developed countries' markets and supply chains. This will not only provide incentives for the green technology innovation but also create new mimetic isomorphism effects in the home country's market and supply chain to enhance Chinese companies' environmental technology and social responsibility.

This research also offers some practical implications. If the EMEs are headquartered in a region with a low level of institutional development, OFDI can act as an opportunity to escape from institutional constraints, let them interact with stakeholders in the new institutional environment in host countries to enhance green innovation. In addition to passively accepting institutional changes, EMEs should also actively explore new markets, resources or intellectual capital through OFDI to break through institution restriction within a transition economy. Furthermore, although institutional changes within a country or region are occurring gradually in the long run, this study suggests that EMEs choose to overcome organisational inertia and compete in a broader market to enhance their awareness and ability of green innovation. In fact, some Chinese EMEs which lacking sense of responsibility, prefer to compete in the domestic market because of dependence on state as 'ease of access' to resources, which are insensitive to institutional pressure. Alternatively, when the local community cannot provide fertile ground for CSR behaviours (e.g. green innovation), EMEs can actively choose to operate across regions or countries for new opportunities. Moreover, this research also suggests that local governments provide support for theinternationalisation (e.g. OFDI) of EMEs, and promote the diffusion of green innovation through reverse absorption and international market competition.

\section{Limitation and future research}

Firstly, we only use the sample of EMEs from the single country (i.e. Chinese firms) in this article; one limitation is the study only concerns the EMEs from China, the biggest emerging countries. If international comparison can be made, such as EMEs from different home countries (e.g. China, South Africa and Brazil), the results will be more meaningful.

Secondly, although we have divided our sample of into OFDI in developed countries and emerging countries, this article does not consider the specific formal and informal institutional differences (e.g. cross-country differences in institutional environments developed by World Bank; Hofstede's Cultural Dimensions). The future research should consider the impact of institutional differences between different countries while quantifying the institutional difference specifically (Wu et al., 2016), and thus let us investigate more drivers of green innovation for EMEs.

\section{Acknowledgements}

The authors thank the helpful comments from the symposium on 'sustainable development and corporate social responsibility (2019)' hosted by the Chinese Institute of Business Administration and Beijing Normal University.

\section{Competing interests}

The authors have declared that no competing interests exist.

\section{Authors' contributions}

Z.Y. was responsible for formal analysis, methodology, writing and correspondence. S.T.A. was responsible for writing of the article. F.A., Z.S. and M.A.K. revised and edited the manuscript.

\section{Ethical consideration}

This article followed all ethical standards for carrying out research. 


\section{Funding information}

This research was supported by the Natural Science Foundation of China (71463028, 71472030, 71533002).

\section{Data availability statement}

Data sharing is not applicable to this article as no new data were created or analysed in this study.

\section{Disclaimer}

The views and opinions expressed in this article are those of the authors and do not necessarily reflect the official policy or position of any affiliated agency of the authors.

\section{References}

Abrahamson, E., \& Rosenkopf, L. (1993). Institutional and competitive Bandwagons: Using mathematical modeling as a tool to explore innovation diffusion. Academy of Management Review, 18(3), 487-517. https://doi.org/10.5465/amr.1993. 9309035148

Acar, O.A., Tarakci, M., \& Knippenberg, D.V. (2019). Creativity and innovation unde constraints. Journal of Management, 45(1), 96-121. https://doi.org/10. 1177/0149206318805832

Aghion, P., Dechezleprêtre, A., Hémous, D., Martin, R., \& Van Reenen, J. (2016). Carbon taxes, path dependency, and directed technical change: Evidence from the auto industry. Journal of Political Economy, 124(1), 1-51. https://doi.org/10. 1086/684581

Arora, B., Kourula, A., \& Phillips, R. (2019). Emerging paradigms of corporate social responsibility, regulation, and governance: Introduction to the thematic symposium. Journal of Business Ethics, 162, 265-268. https://doi.org/10.1007/ s10551-019-04236-2

Batjargal, B., Hitt, M.A., Tsui, A.S., Arregle, J.L., Webb, J.W., \& Miller, T.L. (2013) Institutional polycentrism, entrepreneurs' social networks, and new venture growth. Academy of Management Journal, 56(4), 1024-1049. https://doi. org/10.5465/amj.2010.0095

Bu, M.L., Liu, Z.B., Wagner, M., \& Yu, X.H. (2013). Corporate social responsibility and the pollution haven hypothesis: Evidence from multinationals' investment the pollution haven hypothesis: Evidence from multinationals investment
decision in China. Asia-Pacific Journal of Accounting \& Economics, 20(1), 85-99. decision in China. Asia-Pacific Journal of Accoun
https://doi.org/10.1080/16081625.2013.759175

Cameron, A.C., \& Trivedi, P.K. (2005). Microeconometrics: Methods and applications. Cambridge: Cambridge University Press.

Chattopadhyay, P., George, E., Li, J., \& Gupta, V. (2020). Geographical dissimilarity and team member influence: Do emotions experienced in the initial team meetin matter? Academy of Management Journal, 63. https://doi.org/10.5465/amj. 2017.0744

Choi, S.B., Lee, S.H., \& Williams, C. (2011). Ownership and firm innovation in a transition economy: Evidence from China. Research Policy, 40(3), 441-452. https://doi.org/10.1016/j.respol.2011.01.004

Christmann, P., \& Taylor, G. (2002). Globalization and the environment: Strategies fo international voluntary environmental initiatives. Academy of Management Perspectives, 16(3), 121-135. https://doi.org/10.5465/ame.2002.8540373

Conyon, M.J., He, L., \& Zhou, X. (2015). Star CEOs or political connections? Evidence from China's publicly traded firms. Journal of Business Finance \& Accounting, 42(3-4), 412-443. https://doi.org/10.1111/jbfa.12110

Cornaggia, J., Mao, Y., Tian, X., \& Wolfe, B. (2015). Does banking competition affect innovation? Journal of Financial Economics, 115(1), 189-209. https://doi. org/10.1016/j.jfineco.2014.09.001

DiMaggio, P.J., \& Powell, W.W. (1983). The iron cage revisited: Institutional isomorphism and collective rationality in organizational fields. American Sociological Review, 48(2), 147-160. https://doi.org/10.2307/2095101

Dunning, J.H. (1988). The eclectic paradigm of international production: A restatement and some possible extensions. Journal of International Business Studies, 19(1), 1-31. https://doi.org/10.1057/palgrave.jibs.8490372

Fabrizi, A., Guarini, G., \& Meliciani, V. (2018). Green patents, regulatory policies and research network policies. Research Policy, 47(6), 1018-1031. https://doi. org/10.1016/j.respol.2018.03.005

Flammer, C., \& Kacperczyk, A. (2019). Corporate social responsibility as a defense against knowledge spillovers: Evidence from the inevitable disclosure doctrine. Strategic Management Journal, 40(8), 1243-1267. https://doi.org/10.1002/ smj.3025

Galbreath, J. (2019). Drivers of green innovations: The impact of export intensity, women leaders, and absorptive capacity. Journal of Business Ethics, 158(1), 47-61. https://doi.org/10.1007/s10551-017-3715-z

Gao, G.Y., Murray, J.Y., Kotabe, M., \& Lu, J. (2009). A 'strategy tripod' perspective on export behaviors: Evidence from domestic and foreign firms based in an emerging economy. Journal of International Business Studies, 41(3), 377-396. https://doi. org/10.1057/jibs.2009.27
Hampton, M.P., \& Christensen, J. (2002). Offshore Pariahs? Small island economies, tax havens, and the re-configuration of global finance. World Development, 30(9), 1657-1673. https://doi.org/10.1016/s0305-750x(02)00054-2

He, J., \& Tian, X. (2013). The dark side of analyst coverage: The case of innovation. Journal of Financial Economics, 109(3), 856-878. https://doi.org/10.1016/j. jfineco.2013.04.001

Howell, S.T. (2017). Financing innovation: Evidence from R\&D grants. American Economic Review, 107(4), 1136-1164. https://doi.org/10.1257/aer.20150808

Huang, K.G., \& Li, J. (2019). Adopting knowledge from reverse innovations? Transnational patents and signaling from an emerging economy. Journal of International Business Studies, 50, 1078-1102. https://doi.org/10.1057/s41267019-00241-9

Huang, Y., Ma, Y., Yang, Z., \& Zhang, Y. (2016). A fire sale without fire: An explanation of labor-intensive FDI in China. Journal of Comparative Economics, 44(4), 884901. https://doi.org/10.1016/j.jce.2016.04.007

Jia, N., Huang, K.G., \& Man Zhang, C. (2019). Public governance, corporate governance, and firm innovation: An examination of state-owned enterprises. Academy of Management Journal, 62(1), 220-247. https://doi.org/10.5465/amj.2016.0543

Johanson, J., \& Vahlne, J.-E. (2009). The Uppsala internationalization process model revisited: From liability of foreignness to liability of outsidership. Journal of International Business Studies, 40(9), 1411-1431. https://doi.org/10.1057/ jibs.2009.24

Kang, J. (2013). The relationship between corporate diversification and corporate social performance. Strategic Management Journal, 34(1), 94-109. https://doi org/10.1002/smj.2005

Karkinsky, T., \& Riedel, N. (2012). Corporate taxation and the choice of patent location within multinational firms. Journal of International Economics, 88(1), 176-185. https://doi.org/10.1016/j.jinteco.2012.04.002

Kumar, P., \& Zaheer, A. (in press). Ego-network Stability and Innovation in Alliances. Academy of Management Journal.

Lee, J., Veloso, F.M., \& Hounshell, D.A. (2011). Linking induced technological change, Research Policy, 40(9), 1240-1252. https://doi.org/10.1016/j.respol.2011.06.006

Lev, B., \& Sunder, S. (1979). Methodological issues in the use of financial ratios. Journal of Accounting and Economics, 1(3), 187-210. https://doi org/10.1016/0165-4101(79)90007-7

Levinson, A., \& Taylor, M.S. (2008). Unmasking the pollution haven effect. International Economic Review, 49(1), 223-254. https://doi.org/10.1111/j.1468-2354.2008.00478.x

Li, J., Li, Y., \& Shapiro, D. (2012). Knowledge seeking and outward FDI of emerging market firms: The moderating effect of inward FDI. Global Strategy Journal, 2(4), 277-295. https://doi.org/10.1111/j.2042-5805.2012.01042.x

Li, J., Strange, R., Ning, L., \& Sutherland, D. (2016). Outward foreign direct investment and domestic innovation performance: Evidence from China. Internationa Business Review, 25(5), 1010-1019. https://doi.org/10.1016/j.ibusrev.2016.01.008

Liu, X., Lu, J., \& Chizema, A. (2014). Top executive compensation, regional institutions and Chinese OFDI. Journal of World Business, 49(1), 143-155. https://doi. org/10.1016/j.jwb.2013.04.004

Lu, J., Liu, X., Wright, M., \& Filatotchev, I. (2014). International experience and FD location choices of Chinese firms. Journal of International Business Studies, 45(4), 428-449. https://doi.org/10.1057/jibs.2013.68

Luo, X.R., Wang, D.Q., \& Zhang, J.J. (2017). Whose call to answer: Institutional complexity and firms' CSR reporting. Academy of Management Journal, 60(1), 321-344. https://doi.org/10.5465/amj.2014.0847

Papanastassiou, M., Pearce, R., \& Zanfei, A. (2020). Changing perspectives on the internationalization of R\&D and innovation by multinational enterprises: A review of the literature. Journal of International Business Studies, 51, 623-664. https:// of the literature. Journal of International
doi.org/10.1057/s41267-019-00258-0

Perruchas, F., Consoli, D., \& Barbieri, N. (2020). Specialisation, diversification and the ladder of green technology development. Research Policy, 49(3), 103922. https:// doi.org/10.1016/j.respol.2020.103922

Piperopoulos, P., Wu, J., \& Wang, C. (2018). Outward FDI, location choices and innovation performance of emerging market enterprises. Research Policy, 47(1), 232-240. https://doi.org/10.1016/j.respol.2017.11.001

Popp, D. (2006). International innovation and diffusion of air pollution contro technologies: The effects of NOx and SO2 regulation in the US, Japan, and Germany. Journal of Environmental Economics and Management, 51(1), 46-71. https://doi.org/10.1016/j.jeem.2005.04.006

Russo, A., \& Perrini, F. (2009). Investigating stakeholder theory and social capital: CSR in large firms and SMEs. Journal of Business Ethics, 91(2), 207-221. https://doi. org/10.1007/s10551-009-0079-z

Seru, A. (2014). Firm boundaries matter: Evidence from conglomerates and R\&D activity. Journal of Financial Economics, 111(2), 381-405. https://doi. activity. Journal of Financial
org/10.1016/j.jfineco.2013.11.001

Shu, C., Zhou, K.Z., Xiao, Y., \& Gao, S. (2014). How green management influences product innovation in China: The role of institutional benefits. Journal of Business Ethics, 133(3), 471-485. https://doi.org/10.1007/s10551-014-2401-7

Stefan, A., \& Paul, L. (2008). Does it pay to be green? A systematic overview. Academy of Management Perspectives, 22(4), 45-62. https://doi.org/10.5465/ amp.2008.35590353

Stucki, T. (2019). Which firms benefit from investments in green energy technologies? The effect of energy costs. Research Policy, 48(3), 546-555. https://doi org/10.1016/j.respol.2018.09.010

Sunder, J., Sunder, S.V., \& Zhang, J. (2017). Pilot CEOs and corporate innovation. Journal of Financial Economics, 123(1), 209-224. https://doi.org/10.1016/j. jfineco.2016.11.002 
Van Waarden, F. (2001). Institutions and innovation: The legal environment of innovating firms. Organization Studies, 22(5), 765-795. https://doi.org/10.1177/ 0170840601225002

Wang, C., Hong, J., Kafouros, M., \& Wright, M. (2012). Exploring the role of government involvement in outward FDI from emerging economies. Journal of International Business Studies, 43(7), 655-676. https://doi.org/10.1057/jibs.2012.18

Wang, C., Yi, J., Kafouros, M., \& Yan, Y. (2015). Under what institutional conditions do business groups enhance innovation performance? Journal of Business Research, 68(3), 694-702. https://doi.org/10.1016/j.jbusres.2014.08.002

Wei, Z., Shen, H., Zhou, K.Z., \& Li, J.J. (2015). How does environmental corporate socia responsibility matter in a dysfunctional institutional environment? Evidence from China. Journal of Business Ethics, 140(2), 209-223. https://doi.org/10.1007/s10551-015-2704-3

Wu, J., Wang, C.Q., Hong, J.J., Piperopoulos, P., \& Zhuo, S.H. (2016). Internationalization and innovation performance of emerging market enterprises: The role of hostcountry institutional development. Journal of World Business, 51(2), 251-263. https://doi.org/10.1016/j.jwb.2015.09.002

Xia, J., Boal, K., \& Delios, A. (2009). When experience meets national institutional environmental change: Foreign entry attempts of U.S. firms in the Central and Eastern European region. Strategic Management Journal, 30(12), 1286-1309. https://doi.org/10.1002/smj.794
Xia, J., Ma, X., Lu, J.W., \& Yiu, D.W. (2014). Outward foreign direct investment by emerging market firms: A resource dependence logic. Strategic Management Journal, 35(9), 1343-1363. https://doi.org/10.1002/smj.2157

Xia, J., Tan, J., \& Tan, D. (2008). Mimetic entry and bandwagon effect: The rise and decline of international equity joint venture in China. Strategic Management Journal, 29(2), 195-217. https://doi.org/10.1002/smj.648

Xie, Z., \& Li, J. (2017). Exporting and innovating among emerging market firms: The moderating role of institutional development. Journal of International Business Studies, 49(2), 222-245. https://doi.org/10.1057/s41267-017-0118-4

Xing, G., Xia, B., \& Guo, J. (2019). Sustainable cooperation in the green supply chain under financial constraints. Sustainability, 11(21), 5977. https://doi.org/10.3390/ su11215977

Xu, D., Zhou, K.Z., \& Du, F. (2019). Deviant versus aspirational risk taking: The effects of performance feedback on bribery expenditure and R\&D intensity. Academy of Management Journal, 62(4), 1226-1251. https://doi.org/10.5465/ amj.2016.0749

Zaheer, S. (1995). Overcoming the liability of foreignness. Academy of Management Journal, 38(2), 341-363. https://doi.org/10.5465/256683 